\title{
SGK1-Sensitive Regulation of Cyclin- Dependent Kinase Inhibitor 1B (p27) in Cardiomyocyte Hypertrophy
}

\author{
Jakob Voelkl Tatsiana Castor Katharina Musculus Robert Viereck Sobuj Mia \\ Martina Feger Ioana Alesutan Florian Lang \\ Department of Physiology, University of Tübingen, Tübingen, Germany
}

Key Words

p27 • Acta1 • Isoproterenol $\bullet$ SGK1 • Cardiac hypertrophy $\bullet$ HL-1 cardiomyocytes

\begin{abstract}
Background/Aims: The serum- and glucocorticoid-inducible kinase SGK1 participates in the orchestration of cardiac hypertrophy and remodeling. Signaling linking SGK1 activity to cardiac remodeling is, however, incompletely understood. SGK1 phosphorylation targets include cyclin-dependent kinase inhibitor 1B (p27), a protein which suppresses cardiac hypertrophy. The present study explored how effects of SGK1 on nuclear p27 localization might modulate the hypertrophic response in cardiomyocytes. Methods: Experiments were performed in HL-1 cardiomyocytes and in SGK1-deficient $\left(\mathrm{sgk1}^{-/}\right)$and corresponding wild-type $\left(\mathrm{sgk1}^{+/+}\right)$mice following pressure overload by transverse aortic constriction (TAC). Transcript levels were quantified by RT-PCR, protein abundance by Western blotting and protein localization by confocal microscopy. Results: In HL-1 cardiomyocytes, overexpression of constitutively active SGK1 (SGK1 ${ }^{\text {S422D) }}$ ) but not of inactive SGK1 (SGK1 $1^{\text {K127N }) ~ i n c r e a s e d ~ s i g n i f i c a n t l y ~ t h e ~ c e l l ~}$ size and transcript levels encoding Acta1, a molecular marker of hypertrophy. Those effects were paralleled by almost complete relocation of p27 in the cytoplasm. Treatment of HL-1 cardiomyocytes with isoproterenol was followed by up-regulation of SGK1 expression. Moreover, isoproterenol treatment stimulated the hypertrophic response and was followed by disappearance of p27 from the nuclei, effects prevented by the SGK1 inhibitor EMD638683. The effect of SGK1 $1^{5422 D}$ overexpression on Acta1 mRNA levels was disrupted by overexpression of p27 and of the p27 $27197 \mathrm{~A}$ mutant lacking the SGK1 phosphorylation site, but not of the phosphomimetic p27 $7^{\text {T197D }}$ mutant. In sgk1 $1^{+/+}$mice, TAC increased significantly SGK1 and Acta1 mRNA levels and decreased the nuclear to cytoplasmic protein ratio of p27 in cardiac tissue, effects blunted in the sgk1 1 mice. Conclusion: SGK1-induced hypertrophy of cardiomyocytes involves p27 phosphorylation at T197, which fosters cytoplasmic p27 localization.
\end{abstract}

Florian Lang

KARGER 125
Department of Physiology, University of Tübingen, Gmelinstr. 5, 72076 Tübingen, (Germany)

Tel. +49 707129 72194, Fax +49 707129 5618, E-Mail florian.lang@uni-tuebingen.de 


\begin{tabular}{|c|c|c|}
\hline Cellular Physiology & Cell Physiol Biochem 2015;37:603-614 & \\
\hline and Biochemistry & $\begin{array}{l}\text { DOI: 10.1159/000430380 } \\
\text { Published online: September 08, } 2015\end{array}$ & $\begin{array}{l}\text { O } 2015 \mathrm{~S} \text {. Karger AG, Basel } \\
\text { www.karger.com/cpb }\end{array}$ \\
\hline
\end{tabular}

\section{Introduction}

Cardiac remodeling is a pathophysiological response to a variety of challenges including pressure overload [1] and excessive adrenergic stimulation with isoproterenol [2]. Signaling contributing to cardiac remodeling includes the serum- and glucocorticoid-inducible kinase SGK1 [3-6], a kinase genomically up-regulated by a variety of hormones including glucocorticoids [7], mineralocorticoids [8] and TGF $\beta$ [9]. Stimulators of SGK1 activity include phosphoinositide 3-kinase (PI3K)/phosphoinositide-dependent kinase PDK1 [10] and mammalian target of rapamycin protein complex mTORC2 [11-13]. SGK1 presumably contributes to the known stimulation of cardiac hypertrophy by PI3K and participates in tissue fibrosis [6, 9, 14-17].

Lack of SGK1 counteracts cardiac remodeling during pressure overload [4, 5], mineralocorticoid excess [6], glucocorticoid excess [18] and angiotensin-II infusion [19]. SGK1-dependent mechanisms contributing to cardiac remodeling include stimulation of $\mathrm{Na}^{+} / \mathrm{H}^{+}$exchanger Nhe1 [5, 20] with Nhe1-sensitive [21] expression of osteopontin [5, 22], inflammatory response modulation [19, 23] and late-sodium current activation [4].

SGK1 phosphorylation targets include cyclin-dependent kinase inhibitor 1B (p27) [13], a powerful blocker of cell proliferation [24, 25]. SGK1 and PKB act downstream of PI3K and phosphorylate p27 $7^{\mathrm{T} 157}$ and p27 $7^{\mathrm{T} 198}$ leading to impaired nuclear import of p27 and its accumulation in the cytoplasm [13,26, 27].

P27 is strongly expressed in the heart [24] and down-regulated during and suppressing cardiac remodelling following heart failure [28], pressure overload [29], cardiac hypertrophy $[24,25,30]$ and myocardial infarction [31]. P27 expression is up-regulated by genetic knockout of the Nhe1 [32], which participates in the SGK1-sensitive cardiac remodelling following pressure overload [5]. Genetic knockout of p27 leads to increased heart size and total number of cardiac myocytes [33]. The present study addressed the involvement of p27 in the stimulation of cardiac hypertrophy by SGK1.

\section{Material and Methods}

Constructs and site-directed mutagenesis

The constitutively active SGK1 $1^{\text {S422D }}$ and inactive SGK1 $1^{\mathrm{K} 127 \mathrm{~N}}$ constructs in pcDNA3.1 were described previously [34]. The construct encoding mouse p27 in pCMV-SPORT6 was purchased from Source BioScience LifeSciences. The p27 ${ }^{\mathrm{T} 197 \mathrm{~A}}$ and $\mathrm{p} 27^{\mathrm{T} 197 \mathrm{D}}$ mutants were generated by site-directed mutagenesis using QuikChange II XL Site-Directed Mutagenesis Kit (Stratagene) according to the manufacturer's instructions. The following primers were used $\left(5^{\prime} \rightarrow 3^{\prime}\right.$ orientation $)$ :

p2 $7^{\text {T197A }}$ sense: CGGAGCTGTTTACGCTGGCGTCGAAGGC;

p2 $7^{\text {T197A }}$ antisense: GCCTTCGACGCCAGGCGTAAACAGCTCCG;

p27 $7^{\text {T197D }}$ sense: TTAATTCGGAGCTGTTTAGTCCTGGCGTCGAAGGCCGGG;

p27 ${ }^{\text {T197D }}$ antisense: CCCGGCCTTCGACGCCAGGACTAAACAGCTCCGAATTAA.

Underlined bases indicate mutation sites. The mutants were sequenced to verify the presence of the desired mutations.

\section{Cell culture}

HL-1 cardiomyocytes (kindly provided by Dr. W.C. Claycomb) were maintained in Claycomb medium supplemented with 10\% FBS, 0.1mM norepinephrine, 2mM L-Glutamine (Sigma Aldrich), 100 units/ $\mathrm{ml}$ penicillin and $100 \mu \mathrm{g} / \mathrm{ml}$ streptomycin (Invitrogen). The medium was changed approximately every 24 hours. HL-1 cardiomyocytes were transfected with $2 \mu \mathrm{g}$ DNA encoding constitutively active SGK1 ${ }^{\text {S422D }}$, inactive SGK1 $1^{\mathrm{K} 127 \mathrm{~N}}$, wild-type $\mathrm{p} 27^{\mathrm{WT}}$, p2 $7^{\mathrm{T} 197 \mathrm{~A}}$ mutant, $\mathrm{p} 27^{\mathrm{T} 197 \mathrm{D}}$ mutant or with empty vectors as control using X-tremeGENE HP DNA transfection reagent (Roche) according to the manufacturer's protocol. The cells were used 48 hours after transfection. Transfection efficiency was verified by quantitative RT-PCR. HL-1 cardiomyocytes were treated for 24 hours with $50 \mu \mathrm{M}$ EMD638683 [35] and/or $1 \mu \mathrm{M}$ isoproterenol [36]. Equal amounts of vehicle were used as control.

\section{KARGER}




\section{Cellular Physiology Cell Physiol Biochem 2015;37:603-614 \begin{tabular}{l|l|l} 
DOI: 10.1159/000430380 & C 2015 S. Karger AG, Basel
\end{tabular} and Biochemistry Published online: September 08, 2015 \\ Voelkl et al.: SGK1-Sensitive Cardiac p27}

\section{Murine aortic banding}

All animal experiments were conducted according to the German law for the welfare of animals and were approved by local authorities. The origin of the mice has been described previously [37]. Cardiac pressure overload [38] was induced in 8-11-week-old mice as described [5, 36]. After anesthesia, intubation and ventilation (Harvard apparatus) of the mouse, the transverse aorta was surgically exposed and constricted by the width of a 27-G cannula using a 7-0 suture. Animals were treated with buprenorphine after the procedure. Animals were sacrificed 10 days after the procedure and left ventricular tissues snap frozen in liquid nitrogen.

\section{Quantitative RT-PCR}

Total RNA was isolated from murine heart and HL-1 cardiomyocytes using Trifast Reagent (Peqlab) according to the manufacturer's instructions [39]. Reverse transcription of $2 \mu \mathrm{g}$ RNA was performed using oligo(dT) $)_{12-18}$ primers (Invitrogen) and SuperScript III Reverse Transcriptase (Invitrogen). Quantitative RT-PCR was performed with the iCycleriQ ${ }^{\mathrm{TM}}$ Real-Time PCR Detection System (Bio-Rad Laboratories) and iQSybr Green Supermix (Bio-Rad Laboratories) according to the manufacturer's instructions [40]. The following primers were used $\left(5^{\prime} \rightarrow 3^{\prime}\right.$ orientation):

Acta1 fw: CCCAAAGCTAACCGGGAGAAG;

Acta1 rev: GACAGCACCGCCTGGATAG;

p27 fw: TCTCTTCGGCCCGGTCAAT;

p27 rev: AAATTCCACTTGCGCTGACTC;

Gapdh fw: AGGTCGGTGTGAACGGATTTG;

Gapdh rev: TGTAGACCATGTAGTTGAGGTCA;

SGK1 fw: CTGCTCGAAGCACCCTTACC;

SGK1 rev: TCCTGAGGATGGGACATTTTCA.

The specificity of the PCR products was confirmed by analysis of the melting curves. All PCRs were performed in duplicate and relative mRNA fold changes were calculated by the $2^{-\Delta \Delta C t}$ method using Gapdh as internal reference.

\section{Immunocytochemistry and confocal microscopy}

HL-1 cardiomyocytes were fixed with 4\% paraformaldehyde/PBS for $15 \mathrm{~min}$ at RT and permeabilized with PBS/0.1\% Triton-X for 10 min at RT. After blocking with 5\% normal goat serum in PBS/0.1\% Triton-X for 1 hour at RT, the slides were incubated overnight at $4^{\circ} \mathrm{C}$ with rabbit anti-p27 antibody (diluted 1:50, Abcam) or with rabbit anti-SGK1 antibody (diluted 1:50, Pineda) and then with goat anti-rabbit Alexa Fluor488-conjugated antibody (diluted 1:1,000, Invitrogen) for 1 hour at RT. Nuclei were stained using DRAQ-5 dye (diluted 1:1000, Biostatus) and actin using Rhodamine Phalloidin (diluted 1:100, Invitrogen). The slides were mounted with Prolong Gold antifade reagent (Invitrogen). Images were collected with a confocal laser-scanning microscope (LSM 510, Carl Zeiss MicroImaging GmbH) using a water immersion A-Plan $\times 63 / 1.2 \mathrm{~W}$. Negative controls were carried out simultaneously by omitting incubation with primary antibodies. Cell size was quantified by measuring the area of attached cells in Rhodamine Phalloidin stained HL-1 cardiomyocytes with Zen Lite software (Zeiss). 30 random cells were analyzed in 5-6 pictures of each biological replicate [41].

\section{Extraction of nuclear and cytoplasmic proteins}

The preparation of cytoplasmic and nuclear extracts from murine heart was performed using the NEPER nuclear and cytoplasmic extraction reagents (Thermo Fisher Scientific) according to the manufacturer's instructions. Protein concentration was determined by Bradford assay (Biorad Laboratories).

\section{Protein isolation and Western blotting}

Proteins were isolated from murine heart and from HL-1 cardiomyocytes using IP lysis buffer (Thermo Fisher Sciencific) supplemented with complete protease and phosphatase inhibitor cocktail (Thermo Fisher Sciencific). Protein concentration was determined by Bradford assay (Biorad Laboratories). Equal amounts of proteins were boiled in Roti-Load1 Buffer (Carl Roth) at $100^{\circ} \mathrm{C}$ for $10 \mathrm{~min}$, separated on SDSpolyacrylamide gels and transferred to PVDF membranes [42]. The membranes were incubated overnight at $4^{\circ} \mathrm{C}$ with rabbit anti-p27 antibody (diluted 1:1000, Abcam), rabbit anti-Hdac2 antibody (diluted 1:1000, Cell Signaling), rabbit anti- $\alpha$-tubulin antibody (diluted 1:1000, Cell Signaling) or rabbit anti-Gapdh antibody 


\begin{tabular}{|c|c|c|}
\hline Cellular Physiology & Cell Physiol Biochem 2015;37:603-614 & \\
\hline and Biochemistry & $\begin{array}{l}\text { DOI: } 10.1159 / 000430380 \\
\text { Published online: September 08, } 2015\end{array}$ & $\begin{array}{l}\text { O } 2015 \text { S. Karger AG, Basel } \\
\text { www.karger.com/cpb }\end{array}$ \\
\hline
\end{tabular}

(diluted 1:1000, Cell Signaling) and then with secondary goat anti-rabbit HRP-conjugated antibody (diluted 1:1000, Cell Signaling) for 1 hour at RT. For loading controls, the membranes were stripped in stripping buffer (Thermo Fisher Scientific) for 10 min at RT. Antibody binding was detected with the ECL detection reagent (Thermo Fisher Scientific) and bands were quantified using Quantity One Software (Bio-Rad Laboratories). Results are shown as the normalized ratio of nuclear to cytoplasmic p27 normalized to Hdac2 or $\alpha$-tubulin for the nuclear or the cytoplasmic fraction, respectively or the ratio of total protein to Gapdh normalized to the vector transfected HL-1 cardiomyocytes or sham treated sgk1+/+ mice, respectively.

\section{Statistics}

Data are shown as arithmetic mean \pm SEM. Normality was tested with Shapiro-Wilk test. Non-normal data were log-transformed prior to statistical testing to provide normality. Statistical testing was performed by one-way Anova followed by Tukey-test for homoscedastic data or Games-Howell test for heteroscedastic data. Non-normal data was tested by the Steel-Dwass method. Two groups were compared using unpaired two-tailed t-test. $\mathrm{p}<0.05$ was considered statistically significant.

\section{Results}

In a first series of experiments, HL-1 cardiomyocytes were transfected with empty vector as control, with constitutively active SGK1 (SGK1 ${ }^{\text {S422D }}$ ) or with inactive SGK1 (SGK1 ${ }^{\mathrm{K} 127 \mathrm{~N}}$ ) (Fig. 1D) and the hypertrophic response was determined. As illustrated in Fig. 1, overexpression of constitutively active SGK1 $1^{\text {S422D }}$ but not of inactive SGK1 ${ }^{\mathrm{K} 127 \mathrm{~N}}$ significantly increased the cell size (Fig. 1A, B) and significantly up-regulated Acta1 mRNA expression, a molecular marker

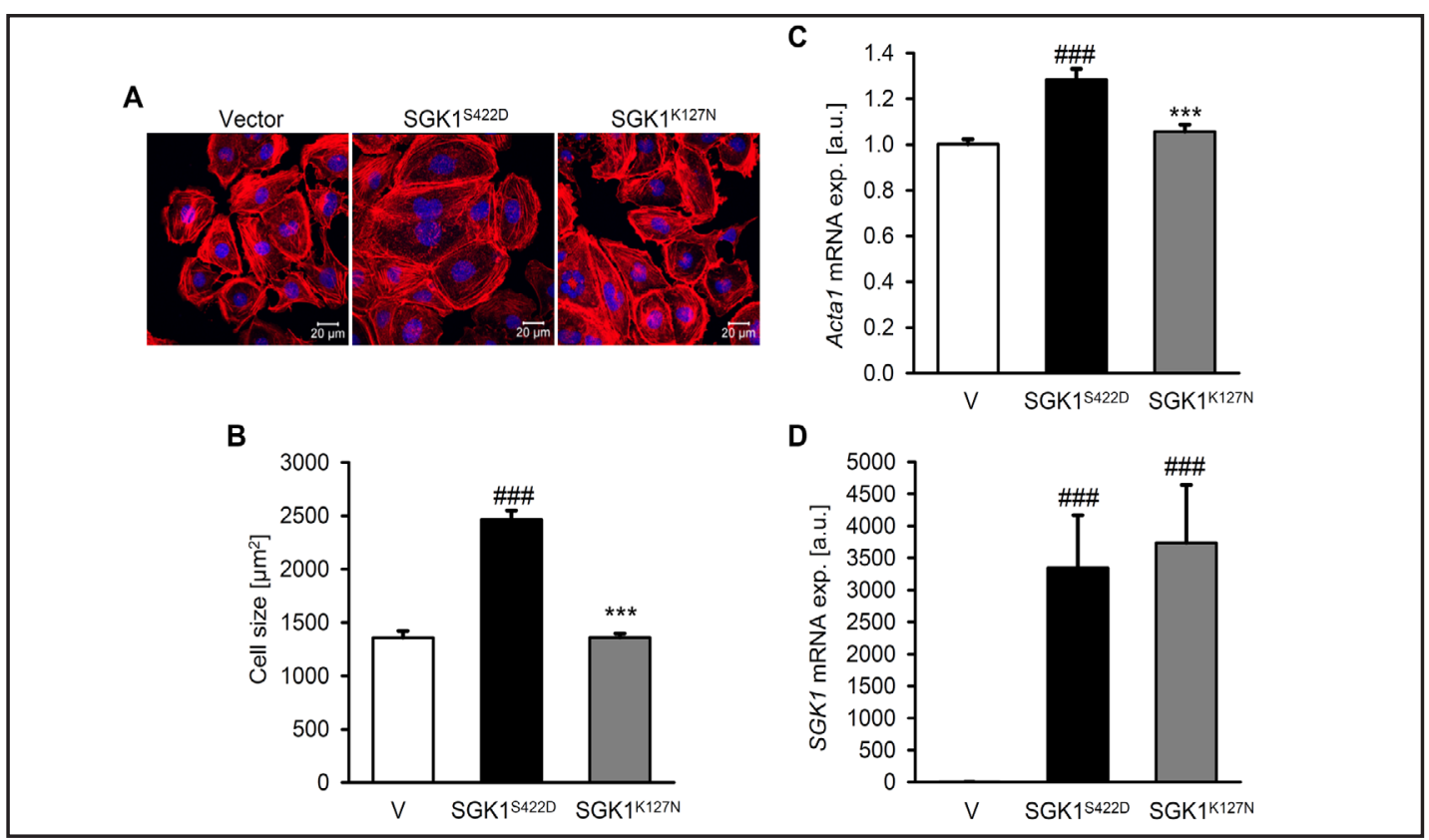

Fig. 1. Effect of SGK1 overexpression on hypertrophic response of HL-1 cardiomyocytes. Confocal microscopy images showing the actin cytoskeleton (A, scale bar: $20 \mu \mathrm{m}$, detected using Rhodamine Phalloidin) in HL-1 cardiomyocytes transfected for 48 hours with empty vector, constitutively active SGK1 ${ }^{\text {S422D }}$ or inactive $\mathrm{SGK} 1^{\mathrm{K} 127 \mathrm{~N}}$. Nuclei are labeled in blue and actin is labeled in red. Images are representative for four independent experiments. Arithmetic means \pm SEM of HL- 1 cardiomyocyte cell size $\left(B, n=4, \mu m^{2}\right)$ transfected for 48 hours with empty vector, constitutively active SGK1 ${ }^{\text {S422D }}$ or inactive SGK1 ${ }^{\mathrm{K} 127 \mathrm{~N}}$. Arithmetic means $\pm \mathrm{SEM}(\mathrm{n}=8$; arbitrary units, a.u.) of Acta1 (C) and SGK1 (D) relative mRNA expression in HL-1 cardiomyocytes transfected for 48 hours with empty vector $(\mathrm{V})$, constitutively active SGK1 ${ }^{\text {S422D }}$ or inactive SGK1 ${ }^{\mathrm{K} 127 \mathrm{~N}}$. \#\#\# $(\mathrm{p}<0.001)$ statistically significant vs. vector transfected HL-1 cardiomyocytes; ${ }^{* * *}(\mathrm{p}<0.001)$ statistically significant vs. SGK1 $1^{\text {S422D }}$ transfected HL-1 cardiomyocytes. 


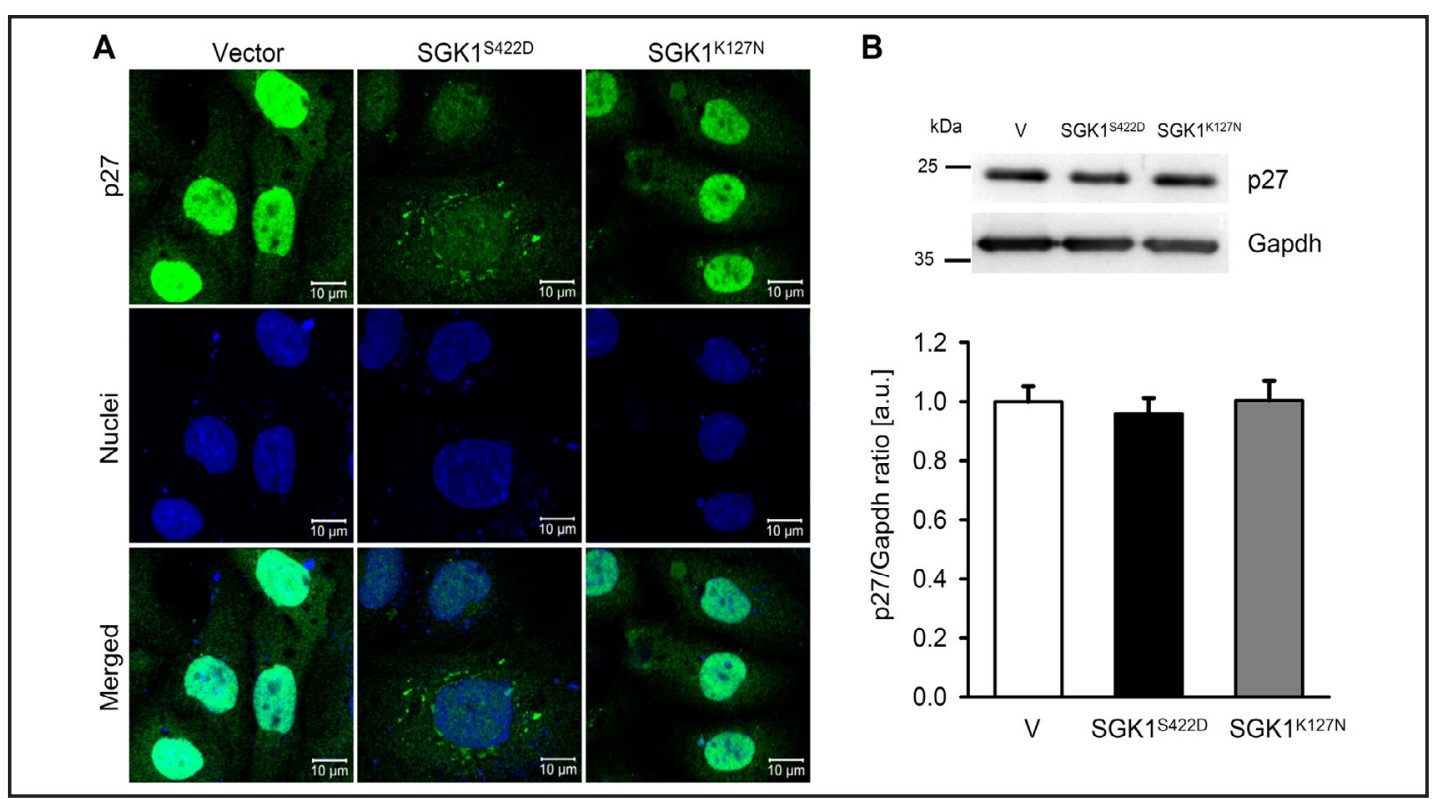

Fig. 2. Effect of SGK1 overexpression on p27 localization and protein abundance in HL-1 cardiomyocytes. Confocal microscopy images showing p27 protein expression and localization (A, scale bar: $10 \mu \mathrm{m})$ in HL-1 cardiomyocytes transfected for 48 hours with empty vector, constitutively active SGK1 ${ }^{\text {S422D }}$ or inactive SGK1 ${ }^{\mathrm{K} 127 \mathrm{~N}}$. P27 expression is represented by green labeling, nuclei are labeled in blue. Images are representative for four independent experiments. Representative original Western blots and arithmetic means \pm SEM (B, n=6; arbitrary units, a.u.) of normalized p27/Gapdh protein ratio in HL-1 cardiomyocytes transfected for 48 hours with empty vector (V), constitutively active SGK1 ${ }^{\text {S422D }}$ or inactive SGK1 ${ }^{\mathrm{K} 127 \mathrm{~N}}$.

Fig. 3. Effect of isoproterenol on SGK1 expression in HL-1 cardiomyocytes. Confocal microscopy images showing SGK1 protein expression and localization (A, scale bar: $10 \mu \mathrm{m})$ in HL-1 cardiomyocytes following treatment for 24 hours with control or with $1 \mu \mathrm{M}$ isoproterenol (ISO). SGK1 expression is represented by green labeling, nuclei are labeled in blue. Images are representative for three independent

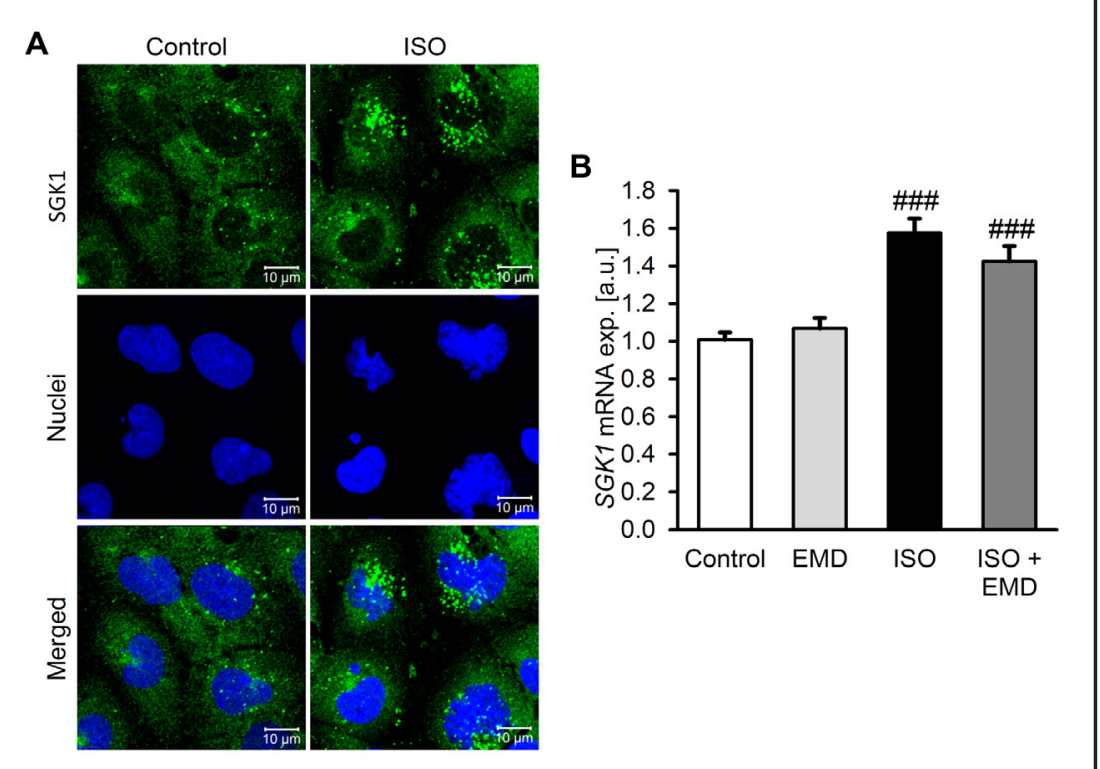
experiments. Arithmetic means \pm SEM (B, $n=12$; arbitrary units, a.u.) of SGK1 relative mRNA expression in HL-1 cardiomyocytes following treatment for 24 hours with control, with $50 \mu \mathrm{M}$ SGK1 inhibitor EMD638683 alone (EMD), with $1 \mu \mathrm{M}$ isoproterenol alone (ISO) or with $1 \mu \mathrm{M}$ isoproterenol and $50 \mu \mathrm{M}$ EMD638683 (ISO+EMD). $\# \# \#(p<0.001)$ statistically significant vs. control treated HL-1 cardiomyocytes.

of hypertrophy (Fig. 1C) in HL-1 cardiomyocytes. Further experiments addressed the effects of SGK1 overexpression on p27 protein abundance and localization. Overexpression of constitutively active SGK1 $1^{\text {S422D }}$ but not of inactive SGK1 ${ }^{\mathrm{K} 127 \mathrm{~N}}$ decreased the nuclear abundance 


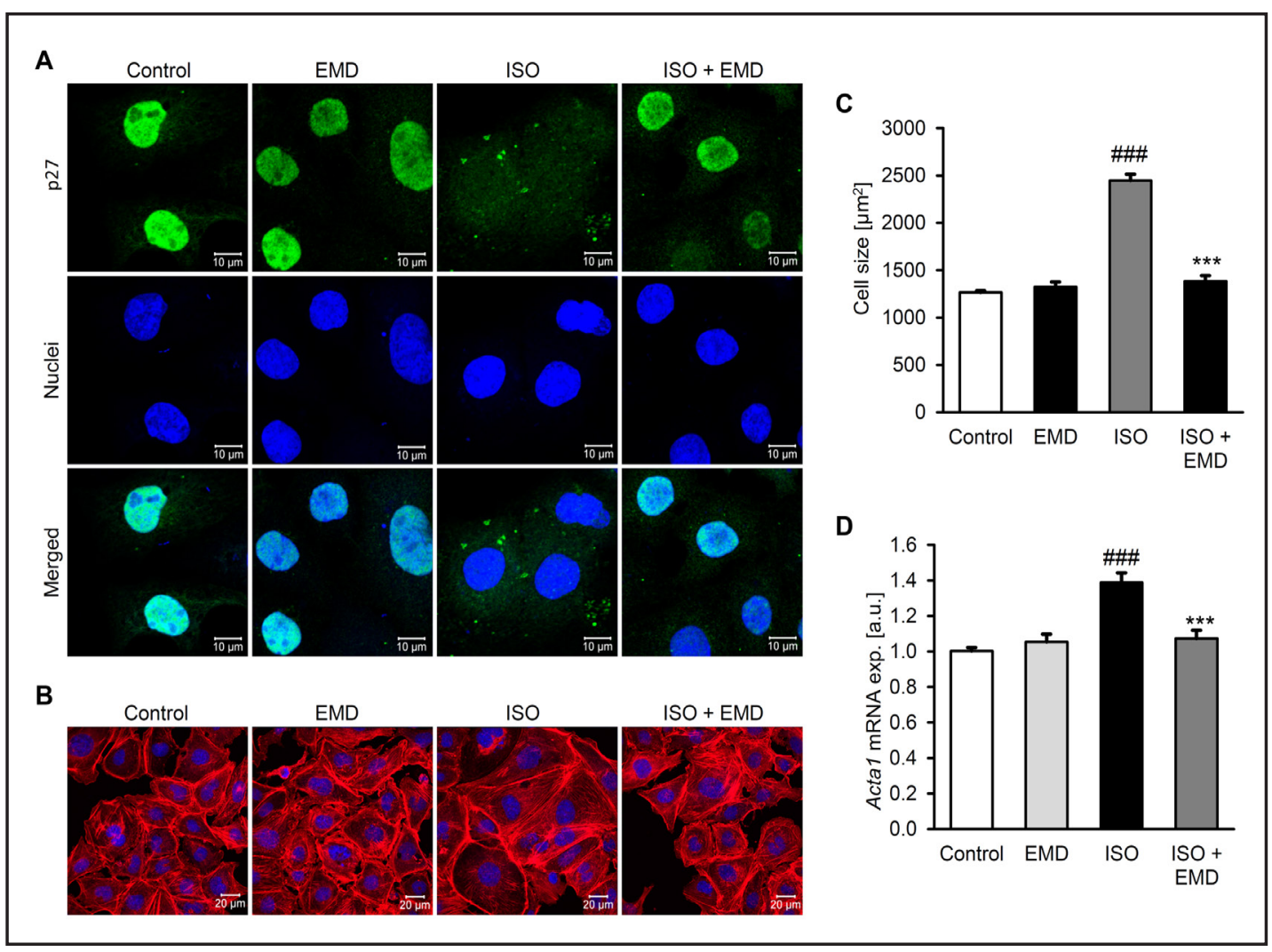

Fig. 4. Effect of SGK1 inhibition on isoproterenol-induced cytoplasmic p27 mislocalization and hypertrophic response of HL-1 cardiomyocytes. Confocal microscopy images showing p27 protein expression and localization (A, scale bar: $10 \mu \mathrm{m}$ ) and the actin cytoskeleton (B, scale bar: $20 \mu \mathrm{m}$, detected using Rhodamine Phalloidin) in HL-1 cardiomyocytes following treatment for 24 hours with control, with $50 \mu$ M SGK1 inhibitor EMD638683 alone (EMD), with $1 \mu \mathrm{M}$ isoproterenol alone (ISO) or with $1 \mu \mathrm{M}$ isoproterenol and $50 \mu \mathrm{M}$ EMD638683 (ISO+EMD). P27 expression is represented by green labeling, nuclei are labeled in blue and actin is labeled in red. Images are representative for four independent experiments. Arithmetic means \pm SEM of HL-1 cardiomyocyte cell size (C, $\left.n=4 ; \mu \mathrm{m}^{2}\right)$ and Acta1 relative mRNA expression (D, $\mathrm{n}=12$; arbitrary units, a.u.) in HL-1 cardiomyocytes following treatment for 24 hours with control, with $50 \mu \mathrm{M}$ EMD638683 alone (EMD), with $1 \mu \mathrm{M}$ isoproterenol alone (ISO) or with $1 \mu \mathrm{M}$ isoproterenol and $50 \mu \mathrm{M}$ EMD638683 (ISO+EMD). \#\#\# ( $<<0.001)$ statistically significant vs. control treated HL-1 cardiomyocytes; ${ }^{* * *}(\mathrm{p}<0.001)$ statistically significant vs. ISO treated HL-1 cardiomyocytes.

of p27 in HL-1 cardiomyocytes (Fig. 2A). However, overexpression of neither, constitutively active SGK1 ${ }^{\text {S422D }}$ nor inactive SGK1 $1^{\mathrm{K} 127 \mathrm{~N}}$ significantly modified $\mathrm{p} 27$ total protein abundance in HL-1 cardiomyocytes (Fig. 2B), indicating that SGK1 primarily regulates p27 subcellular localization.

To gain further insight into SGK1-sensitive regulation of p27, an additional series of experiments was performed in HL-1 cardiomyocytes treated with isoproterenol in the absence or presence of the SGK1 inhibitor EMD638683. As shown by immunostaining with subsequent confocal microscopy, isoproterenol treatment of HL-1 cardiomyocytes was followed by an up-regulation of SGK1 protein abundance, which mainly localized to the cytoplasm (Fig. 3A). Isoproterenol increased SGK1 mRNA expression, an effect not significantly modified by the SGK1 inhibitor EMD638683 in HL-1 cardiomyocytes (Fig. 3B). Furthermore, isoproterenol induced the virtually complete disappearance of p27 from the nuclei of HL-1 cardiomyocytes, an effect prevented by EMD638683 (Fig. 4A). EMD638683 abolished the isoproterenol-induced increase of cell size (Fig. 4B, C) and up-regulation of Acta1 mRNA expression (Fig. 4D).

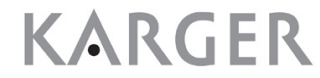




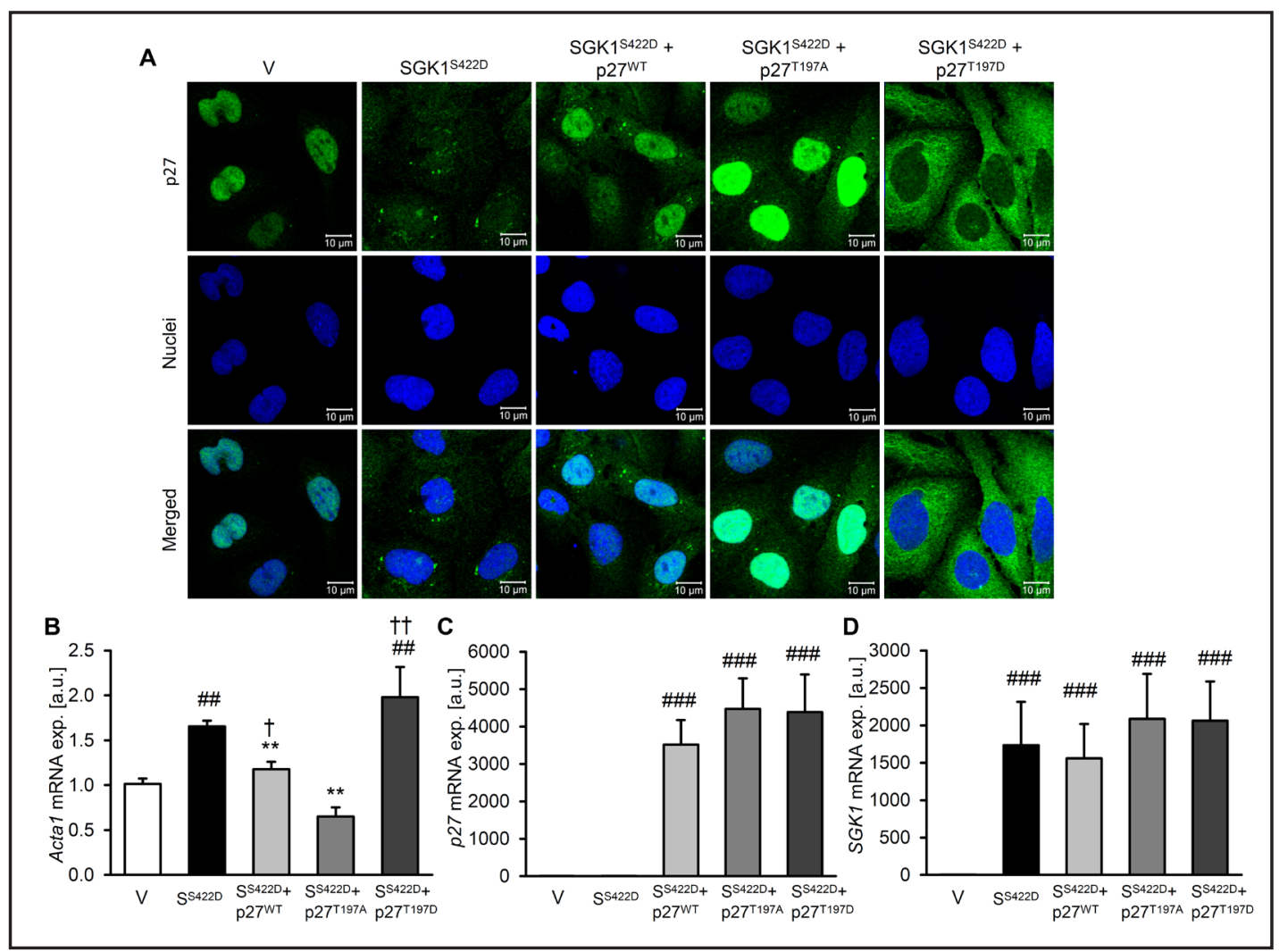

Fig. 5. Role of p27 ${ }^{\mathrm{T} 197}$ phosphorylation on SGK1-induced hypertrophic response of HL-1 cardiomyocytes. Confocal microscopy images showing p27 protein expression and localization (A, scale bar: $10 \mu \mathrm{m}$ ) in HL-1 cardiomyocytes transfected for 48 hours with empty vectors (V) and with constitutively active SGK1 ${ }^{\text {S422D }}$ without or with co-transfection with wild-type p27 (p27 ${ }^{\mathrm{WT}}$ ), p27 $7^{\mathrm{T} 197 \mathrm{~A}}$ mutant lacking the T197 phosphorylation site $\left(\mathrm{p} 27^{\mathrm{T} 197 \mathrm{~A}}\right)$ or phosphomimetic p27 ${ }^{\mathrm{T} 197 \mathrm{D}}$ mutant $\left(\mathrm{p} 27^{\mathrm{T} 197 \mathrm{D}}\right)$. P27 expression is represented by green labeling, nuclei are labeled in blue. Images are representative for three independent experiments. Arithmetic means \pm SEM ( $\mathrm{n}=10$; arbitrary units, a.u.) of Acta1 (B), p27 (Cdkn1b; C) and SGK1 (D) relative mRNA expression in HL-1 cardiomyocytes transfected for 48 hours with empty vectors (V) and with constitutively active SGK1 $1^{\text {S422D }}$ without or with co-transfection with wild-type p27 (p27 ${ }^{\mathrm{WT}}$ ), p27 ${ }^{\mathrm{T} 197 \mathrm{~A}}$ mutant lacking the T197

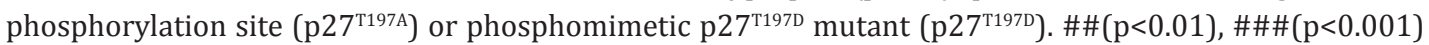
statistically significant vs. vector transfected HL-1 cardiomyocytes; ${ }^{* *}(\mathrm{p}<0.01)$ statistically significant vs. SGK1 $1^{\text {S422D }}$ transfected HL- 1 cardiomyocytes; $\dagger(\mathrm{p}<0.05)$, $\dagger+(\mathrm{p}<0.01)$ statistically significant vs. SGK1 ${ }^{\text {S422D }}$ and p27 ${ }^{\mathrm{T} 197 \mathrm{~A}}$ transfected HL-1 cardiomyocytes.

Phosphorylation of human p27 ${ }^{\mathrm{T} 198}$, a SGK1 phosphorylation site corresponding to murine p27 ${ }^{\mathrm{T} 197}$, is known to interfere with the nuclear import of p27 [13]. The effects of p27 ${ }^{\mathrm{T} 197}$ phosphorylation on SGK1-induced hypertrophic response were assayed by overexpression of wild-type p27 (p27 $7^{\mathrm{WT}}$ ), of p27 $7^{\mathrm{T} 197 \mathrm{~A}}$ mutant lacking the T197 phosphorylation site or of phosphomimetic p27 $7^{\mathrm{T} 197 \mathrm{D}}$ mutant with overexpression of constitutively active SGK1 $1^{\mathrm{S} 22 \mathrm{D}}$ in HL-1 cardiomyocytes (Fig. 5C, D). As shown in Fig. 5A by confocal microscopy, transfection with constitutively active SGK1 $1^{\text {S422D }}$ was followed by disappearance of p27 from the nuclei, an effect slightly ameliorated by overexpression of $\mathrm{p} 27^{\mathrm{WT}}$, which was found in the nucleus and increased in the cytoplasm. The p2 ${ }^{\text {T197A }}$ mutant localized predominantly to the nuclei, while the $\mathrm{p} 27^{\mathrm{T} 197 \mathrm{D}}$ localized exclusively to the cytoplasm, thereby confirming the role of SGK1 on T197-meditated regulation of p27 cellular localization. Furthermore, the Acta1 mRNA expression was significantly up-regulated in constitutively active SGK1 ${ }^{\text {S422D }}$ transfected HL-1

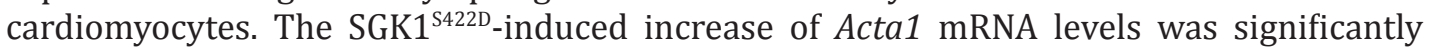
lower following overexpression of $\mathrm{p} 27^{\mathrm{WT}}$, even more suppressed following overexpression 
A

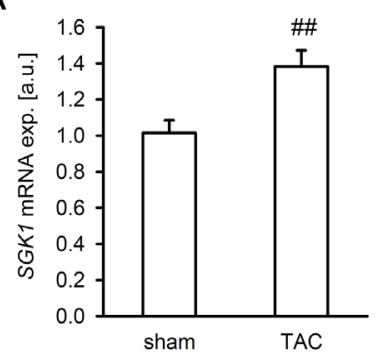

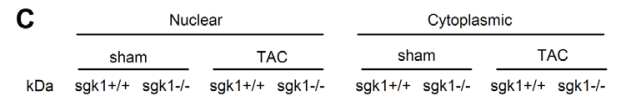

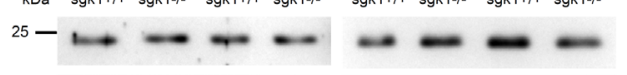

$70--\cdots-$

$55-\cdots-\cdots$

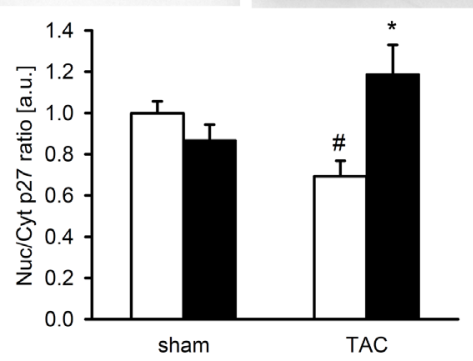

B

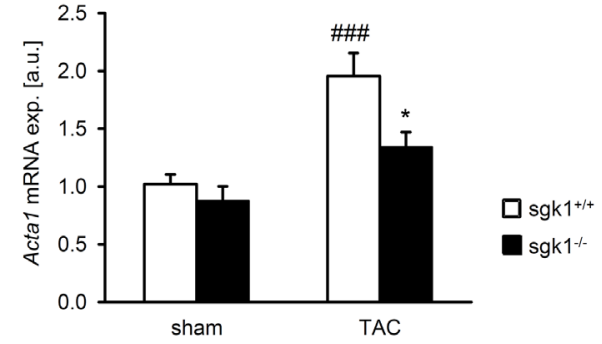

D
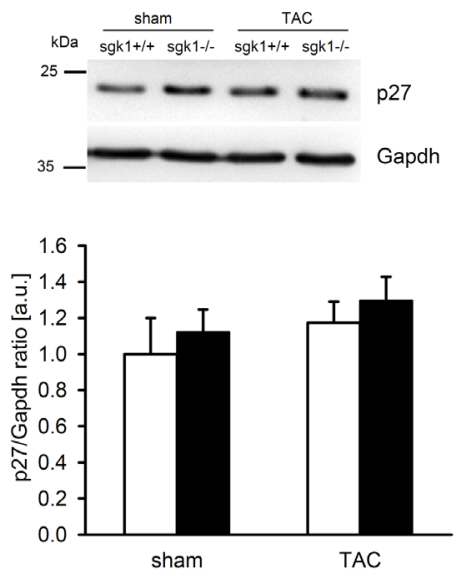

Fig. 6. SGK1-dependent cardiac p27 localization and hypertrophic response following TAC. Arithmetic means \pm SEM (n=7; arbitrary units, a.u.) of SGK1 (A) and Acta1 (B) relative mRNA expression in cardiac tissue from SGK1-deficient (black bars, sgk1 ${ }^{-/}$) and respective wild-type mice (white bars, sgk1 $1^{++}$) following sham (sham) or transverse aortic constriction (TAC). Representative original Western blots and arithmetic means \pm SEM of normalized nuclear to cytoplasmic p27 protein ratio $(C, n=12 ; a . u)$ normalized to Hdac2 and $\alpha$-tubulin protein in the nuclear fraction and cytoplasmic fraction respectively, and of normalized p27/ Gapdh protein ratio (D, $\mathrm{n}=6$; a.u.) in cardiac tissue from SGK1-deficient (black bars, sgk ${ }^{1 /}$ ) and respective wild-type mice (white bars, sgk1 $1^{+/}$) following sham (sham) or transverse aortic constriction (TAC). $\#(\mathrm{p}<0.05), \# \#(\mathrm{p}<0.01), \# \# \#(\mathrm{p}<0.001)$ statistically significant vs. respective sham mice; ${ }^{*}(\mathrm{p}<0.05)$ statistically significant vs. respective $\mathrm{sgk} 1^{+/+}$mice.

of $\mathrm{p} 27^{\mathrm{T} 197 \mathrm{~A}}$, but unchanged following overexpression of the phosphomimetic p27 ${ }^{\mathrm{T} 197 \mathrm{D}}$ mutant (Fig. 5B). Taken together, phosphorylation of p27 at T197 down-regulated nuclear localization of p27 and was apparently required for the SGK1-induced hypertrophic response in cardiomyocytes.

Additional experiments were performed in SGK1-deficient ( $\mathrm{sgk} 1^{\%}$ ) and respective wild-type mice $\left(\mathrm{sgk}^{+/+}\right)$subjected to pressure overload by transverse aortic constriction (TAC). TAC induced a significant increase of SGK1 mRNA expression in cardiac tissue of sgk1 $1^{+/+}$mice (Fig. 6A). Moreover, TAC was followed by a significant up-regulation of Acta1 mRNA expression in cardiac tissue of $s g k 1^{+/+}$mice as compared to sham treated mice, an effect significantly blunted in the sgk $1 \%$ mice (Fig. 6B). TAC treatment further significantly decreased nuclear p27 localization in cardiac tissue of $\mathrm{sgk} 1^{+/+}$mice as compared to sham treated mice, an effect completely lacking in the sgk $1 \%$ mice (Fig. 6C). Accordingly, the nuclear p27 localization was significantly higher in cardiac tissue of sgk $1^{\%}$ mice than of $\mathrm{sgk} 1^{+/+}$mice following TAC. Again, no significant differences of p27 total protein abundance between the groups was observed (Fig. 6D). 


\begin{tabular}{|c|c|c|}
\hline Cellular Physiology & Cell Physiol Biochem 2015;37:603-614 & \\
\hline and Biochemistry & $\begin{array}{l}\text { DOI: 10.1159/000430380 } \\
\text { Published online: September 08, } 2015\end{array}$ & $\begin{array}{l}\text { O } 2015 \text { S. Karger AG, Basel } \\
\text { www.karger.com/cpb }\end{array}$ \\
\hline
\end{tabular}

\section{Discussion}

The present study reveals SGK1-sensitive regulation of cyclin-dependent kinase inhibitor 1B (p27) in cardiomyocytes. Similar to earlier observations [3-5], SGK1 inhibition ameliorates cardiac hypertrophy as indicated by Acta 1 expression. The effects ofSGK1 involved p27 phosphorylation. SGK1 phosphorylates p2 $7^{\mathrm{T} 157}$ (site lacking in the mouse p27 sequence) and $\mathrm{p} 27^{\mathrm{T} 198}$ (corresponding to the mouse p27 ${ }^{\mathrm{T} 197}$ site) thereby decreasing nuclear import of p27 leading to a mislocalization of this protein in the cytoplasm [13]. In both, human and mouse p27, the T198/T197 phosphorylation site represents an optimal consensus sequence specific for SGK1 phosphorylation site recognition motif (RRXS/T, where X is any amino acid, and $\mathrm{S} / \mathrm{T}$ is the phosphorylated residue) [43]. In SGK1 ${ }^{\text {S422D }}$ transfected HL-1 cardiomyocytes the overexpressed p27 was found in the cytoplasm, but also still observed in the nucleus. P27 transfection slightly but significantly decreased Acta1 mRNA expression, an effect possibly due to incomplete phosphorylation of overexpressed p27 or incomplete inhibition of p27 by SGK1-dependent phosphorylation. The SGK1 insensitive p27 ${ }^{\text {T197A }}$ mutant was found in the nucleus, while the phosphomimetic p2 $7^{\mathrm{T} 197 \mathrm{D}}$ mutant localized to the cytoplasm, confirming the regulation of $\mathrm{p} 27$ localization by Sgk1-dependent phosphorylation of $\mathrm{p} 27^{\mathrm{T} 197}$. Acta1 mRNA expression was markedly decreased by overexpression of SGK1 insensitive p27 ${ }^{\text {T197A }}$ mutant, but not by the phosphomimetic p27 ${ }^{\mathrm{T} 197 \mathrm{D}}$ mutant, indicating that SGK1-induced cardiac hypertrophy requires $\mathrm{p} 27^{\mathrm{T} 197}$ phosphorylation.

P27 overexpression, which shows nuclear localization, prevents cardiac hypertrophy in rat hearts after myocardial infarction [31]. P27 is down-regulated in the failing human heart [44] and p27 inactivation is required for cardiac hypertrophy [24]. In failing hearts, increased cytoplasmic localization of p27 was observed [45]. Cytoplasmic p27 is subject to proteasomal degradation [46]. However, T198 phosphorylation apparently leads to cytoplasmic localization of p27 without accelerating its degradation $[47,48]$. No differences in total p27 protein levels were observed in hypertrophic mouse hearts or SGK1 transfected HL-1 cardiomyocytes.

Anti-hypertrophic effects of p27 involve casein kinase II-alpha [24]. The exact downstream effectors of p27 in cardiomyocytes are, however, still elusive [24]. P27 presumably controls a currently unknown factor to prevent cardiac hypertrophy. The heart does not express high levels of the p27 target cyclin E-Cdk2 [24]. Cytoplasmic p27 has distinct signalling effects from nuclear cell cycle inhibition, including activation of STAT3 [49]. Accordingly, SGK1-deficient mice show impaired cardiac STAT3 activation [19]. SGK1 presumably stimulates the $\mathrm{Na}^{+} / \mathrm{H}^{+}$exchangers Nhe1 [17] and Spp1 expression [22], the voltage-gated sodium channel complex Nav1.5 [4] and Gsk3 $\beta$ [50] by direct phosphorylation $[3,4,17]$. All are implicated as effectors in cardiac hypertrophy and remodeling $[4,17,20,21$, $51,52]$. To which extent these effects are related to cytoplasmic p 27 re-localization during cardiac hypertrophy remains to be shown. More than one pathway may be involved in the effects of SGK1 on cardiac hypertrophy.

In conclusion, the current observations show that SGK1 impairs nuclear abundance of p27 and suggest that phosphorylation of $\mathrm{p}^{27^{\mathrm{T} 197}}$ by SGK1 is required for cardiac hypertrophy.

\section{Abbreviations}

SGK1 (serum- and glucocorticoid-inducible kinase 1); Cdkn1b (cyclin-dependent kinase inhibitor 1B); TAC (transverse aortic constriction); Acta1 (actin, alpha skeletal muscle); Nhe1 $\left(\mathrm{Na}^{+} / \mathrm{H}^{+}\right.$exchanger); PI3K (phosphoinositide 3-kinase).

\section{Acknowledgements}

This work was supported by grants from the Deutsche Forschungsgemeinschaft and Open Access Publishing Fund of Tuebingen University. 


\section{Cellular Physiology Cell Physiol Biochem 2015;37:603-614 \begin{tabular}{l|l|l}
\hline DOI: 10.1159/000430380 & (c) 2015 S. Karger AG, Basel
\end{tabular} and Biochemistry Published online: September 08, 2015 \\ Voelkl et al.: SGK1-Sensitive Cardiac p27}

We do confirm that the funder had played no role in study design, collection, analysis and interpretation of data, writing of the report and in the decision to submit the article for publication.

The authors gratefully acknowledge Prof. Dr. W.C. Claycomb for providing the HL-1 cardiomyocytes, the outstanding technical assistance of E. Faber and preparation of the manuscript by T. Loch.

\section{Disclosure Statement}

The authors of this manuscript state that they have no conflicts of interest to declare.

\section{References}

1 Petriz BA, Franco OL: Effects of hypertension and exercise on cardiac proteome remodelling. Biomed Res Int 2014;2014:634132.

2 Nichtova Z, Novotova M, Kralova E, Stankovicova T: Morphological and functional characteristics of models of experimental myocardial injury induced by isoproterenol. Gen Physiol Biophys 2012;31:141-151.

3 Aoyama T, Matsui T, Novikov M, Park J, Hemmings B, Rosenzweig A: Serum and glucocorticoid-responsive kinase-1 regulates cardiomyocyte survival and hypertrophic response. Circulation 2005;111:1652-1659.

4 Das S, Aiba T, Rosenberg M, Hessler K, Xiao C, Quintero PA, Ottaviano FG, Knight AC, Graham EL, Bostrom P, Morissette MR, del Monte F, Begley MJ, Cantley LC, Ellinor PT, Tomaselli GF, Rosenzweig A: Pathological role of serum- and glucocorticoid-regulated kinase 1 in adverse ventricular remodeling. Circulation 2012;126:2208-2219.

5 Voelkl J, Lin Y, Alesutan I, Ahmed MS, Pasham V, Mia S, Gu S, Feger M, Saxena A, Metzler B, Kuhl D, Pichler BJ, Lang F: Sgk1 sensitivity of $\mathrm{Na}(+) / \mathrm{H}(+)$ exchanger activity and cardiac remodeling following pressure overload. Basic Res Cardiol 2012;107:236.

6 Vallon V, Wyatt AW, Klingel K, Huang DY, Hussain A, Berchtold S, Friedrich B, Grahammer F, Belaiba RS, Gorlach A, Wulff P, Daut J, Dalton ND, Ross J, Jr., Flogel U, Schrader J, Osswald H, Kandolf R, Kuhl D, Lang F: SGK1-dependent cardiac CTGF formation and fibrosis following DOCA treatment. J Mol Med 2006;84:396404.

7 Firestone GL, Giampaolo JR, O'Keeffe BA: Stimulus-dependent regulation of serum and glucocorticoid inducible protein kinase (SGK) transcription, subcellular localization and enzymatic activity. Cell Physiol Biochem 2003;13:1-12.

8 McCormick JA, Bhalla V, Pao AC, Pearce D: SGK1: a rapid aldosterone-induced regulator of renal sodium reabsorption. Physiology (Bethesda) 2005;20:134-139.

9 Lang F, Klingel K, Wagner CA, Stegen C, Warntges S, Friedrich B, Lanzendorfer M, Melzig J, Moschen I, Steuer S, Waldegger S, Sauter M, Paulmichl M, Gerke V, Risler T, Gamba G, Capasso G, Kandolf R, Hebert SC, Massry SG, Broer S: Deranged transcriptional regulation of cell-volume-sensitive kinase hSGK in diabetic nephropathy. Proc Natl Acad Sci U S A 2000;97:8157-8162.

10 Alessi DR, Cohen P: Mechanism of activation and function of protein kinase B. Curr Opin Genet Dev 1998;8:55-62.

11 Lu M, Wang J, Ives HE, Pearce D: mSIN1 protein mediates SGK1 protein interaction with mTORC2 protein complex and is required for selective activation of the epithelial sodium channel. J Biol Chem 2011;286:30647-30654.

12 Gleason CE, Frindt G, Cheng CJ, Ng M, Kidwai A, Rashmi P, Lang F, Baum M, Palmer LG, Pearce D: mTORC2 regulates renal tubule sodium uptake by promoting ENaC activity. J Clin Invest 2015;125:117-128.

13 Hong F, Larrea MD, Doughty C, Kwiatkowski DJ, Squillace R, Slingerland JM: mTOR-raptor binds and activates SGK1 to regulate p27 phosphorylation. Mol Cell 2008;30:701-711.

14 Feng Y, Wang Q, Wang Y, Yard B, Lang F: SGK1-mediated fibronectin formation in diabetic nephropathy. Cell Physiol Biochem 2005;16:237-244. 


\section{Cellular Physiology Cell Physiol Biochem 2015;37:603-614 \begin{tabular}{l|l|l} 
DOI: 10.1159/000430380 & (C)15 S. Karger AG, Basel
\end{tabular} and Biochemistry Published online: September 08, 2015 \\ Voelkl et al.: SGK1-Sensitive Cardiac p27}

15 Waldegger S, Klingel K, Barth P, Sauter M, Rfer ML, Kandolf R, Lang F: h-sgk serine-threonine protein kinase gene as transcriptional target of transforming growth factor beta in human intestine. Gastroenterology 1999;116:1081-1088.

16 Damilano F, Perino A, Hirsch E: PI3K kinase and scaffold functions in heart. Ann NY Acad Sci 2010;1188:3945.

17 Voelkl J, Mia S, Meissner A, Ahmed MS, Feger M, Elvira B, Walker B, Alessi DR, Alesutan I, Lang F: PKB/SGKresistant GSK-3 signaling following unilateral ureteral obstruction. Kidney Blood Press Res 2013;38:156164.

18 Voelkl J, Pasham V, Ahmed MS, Walker B, Szteyn K, Kuhl D, Metzler B, Alesutan I, Lang F: Sgk1-dependent stimulation of cardiac Na+/H+ exchanger Nhe1 by dexamethasone. Cell Physiol Biochem 2013;32:25-38.

19 Yang M, Zheng J, Miao Y, Wang Y, Cui W, Guo J, Qiu S, Han Y, Jia L, Li H, Cheng J, Du J: Serum-glucocorticoid regulated kinase 1 regulates alternatively activated macrophage polarization contributing to angiotensin II-induced inflammation and cardiac fibrosis. Arterioscler Thromb Vasc Biol 2012;32:1675-1686.

20 Fliegel L: Regulation of the $\mathrm{Na}(+) / \mathrm{H}(+)$ exchanger in the healthy and diseased myocardium. Expert Opin Ther Targets 2009;13:55-68.

21 Xue J, Mraiche F, Zhou D, Karmazyn M, Oka T, Fliegel L, Haddad GG: Elevated myocardial Na+/H+ exchanger isoform 1 activity elicits gene expression that leads to cardiac hypertrophy. Physiol Genomics 2010;42:374383.

22 Mohamed IA, Gadeau AP, Fliegel L, Lopaschuk G, Mlih M, Abdulrahman N, Fillmore N, Mraiche F: Na+/H+ exchanger isoform 1-induced osteopontin expression facilitates cardiomyocyte hypertrophy. PLoS One 2015;10:e0123318.

23 Schmid E, Xuan NT, Zahir N, Russo A, Yang W, Kuhl D, Faggio C, Shumilina E, Lang F: Serum- and glucocorticoid-inducible kinase 1 sensitive NF-kappaB signaling in dendritic cells. Cell Physiol Biochem 2014;34:943-954.

24 Hauck L, Harms C, An J, Rohne J, Gertz K, Dietz R, Endres M, von Harsdorf R: Protein kinase CK2 links extracellular growth factor signaling with the control of p27(Kip1) stability in the heart. Nat Med 2008;14:315-324.

25 Hinrichsen R, Haunso S, Busk PK: Different regulation of p27 and Akt during cardiomyocyte proliferation and hypertrophy. Growth Factors 2007;25:132-140.

26 Motti ML, De Marco C, Califano D, Fusco A, Viglietto G: Akt-dependent T198 phosphorylation of cyclindependent kinase inhibitor p27kip1 in breast cancer. Cell Cycle 2004;3:1074-1080.

27 Viglietto G, Motti ML, Bruni P, Melillo RM, D'Alessio A, Califano D, Vinci F, Chiappetta G, Tsichlis P, Bellacosa A, Fusco A, Santoro M: Cytoplasmic relocalization and inhibition of the cyclin-dependent kinase inhibitor p27(Kip1) by PKB/Akt-mediated phosphorylation in breast cancer. Nat Med 2002;8:1136-1144.

28 Su M, Wang J, Wang C, Wang X, Dong W, Qiu W, Wang Y, Zhao X, Zou Y, Song L, Zhang L, Hui R: MicroRNA-221 inhibits autophagy and promotes heart failure by modulating the p27/CDK2/mTOR axis. Cell Death Differ 2015;22:986-999.

29 Kang L, Ge CJ, Hu SJ: Beneficial effect of atorvastatin on left ventricular remodeling in spontaneously hypertensive rats. Pharmacology 2007;80:120-126.

30 Li JM, Brooks G: Downregulation of cyclin-dependent kinase inhibitors p21 and p27 in pressure-overload hypertrophy. Am J Physiol 1997;273:H1358-1367.

31 Konecny F, Zou J, Husain M, von Harsdorf R: Post-myocardial infarct p27 fusion protein intravenous delivery averts adverse remodelling and improves heart function and survival in rodents. Cardiovasc Res 2012;94:492-500.

32 Yu L, Quinn DA, Garg HG, Hales CA: Deficiency of the NHE1 gene prevents hypoxia-induced pulmonary hypertension and vascular remodeling. Am J Respir Crit Care Med 2008;177:1276-1284.

33 Poolman RA, Li JM, Durand B, Brooks G: Altered expression of cell cycle proteins and prolonged duration of cardiac myocyte hyperplasia in p27 KIP1 knockout mice. Circ Res 1999;85:117-127.

34 Eylenstein A, Gehring EM, Heise N, Shumilina E, Schmidt S, Szteyn K, Munzer P, Nurbaeva MK, Eichenmuller M, Tyan L, Regel I, Foller M, Kuhl D, Soboloff J, Penner R, Lang F: Stimulation of Ca2+-channel Orai1/STIM1 by serum- and glucocorticoid-inducible kinase 1 (SGK1). FASEB J 2011;25:2012-2021.

35 Towhid ST, Liu GL, Ackermann TF, Beier N, Scholz W, Fuchss T, Toulany M, Rodemann HP, Lang F: Inhibition of colonic tumor growth by the selective SGK inhibitor EMD638683. Cell Physiol Biochem 2013;32:838848. 


\section{Cellular Physiology Cell Physiol Biochem 2015;37:603-614 \begin{tabular}{l|l|l}
\hline DOI: 10.1159/000430380 & (C) 2015 S. Karger AG, Basel
\end{tabular} www.karger.com/cpb \\ Voelkl et al.: SGK1-Sensitive Cardiac p27}

36 Voelkl J, Alesutan I, Pakladok T, Viereck R, Feger M, Mia S, Schonberger T, Noegel AA, Gawaz M, Lang F: Annexin A7 deficiency potentiates cardiac NFAT activity promoting hypertrophic signaling. Biochem Biophys Res Commun 2014;445:244-249.

37 Wulff P, Vallon V, Huang DY, Volkl H, Yu F, Richter K, Jansen M, Schlunz M, Klingel K, Loffing J, Kauselmann G, Bosl MR, Lang F, Kuhl D: Impaired renal $\mathrm{Na}(+)$ retention in the sgk1-knockout mouse. J Clin Invest 2002;110:1263-1268.

38 Rockman HA, Ross RS, Harris AN, Knowlton KU, Steinhelper ME, Field LJ, Ross J, Jr., Chien KR: Segregation of atrial-specific and inducible expression of an atrial natriuretic factor transgene in an in vivo murine model of cardiac hypertrophy. Proc Natl Acad Sci U S A 1991;88:8277-8281.

39 Feger M, Mia S, Pakladok T, Nicolay JP, Alesutan I, Schneider SW, Voelkl J, Lang F: Down-regulation of renal klotho expression by Shiga toxin 2. Kidney Blood Press Res 2014;39:441-449.

40 Alesutan I, Feger M, Pakladok T, Mia S, Ahmed MS, Voelkl J, Lang F: 25-Hydroxyvitamin D3 1-alphahydroxylase-dependent stimulation of renal klotho expression by spironolactone. Kidney Blood Press Res 2013;37:475-487.

41 Fang X, Robinson J, Wang-Hu J, Jiang L, Freeman DA, Rivkees SA, Wendler CC: Cyclic AMP induces hypertrophy and alters DNA methylation in HL-1 cardiomyocytes. Am J Physiol Cell Physiol 2015;10.1152/ ajpcell.00058.2015ajpcell 0005802015.

42 Feger M, Fajol A, Lebedeva A, Meissner A, Michael D, Voelkl J, Alesutan I, Schleicher E, Reichetzeder C, Hocher B, Qadri SM, Lang F: Effect of carbon monoxide donor CORM-2 on vitamin D3 metabolism. Kidney Blood Press Res 2013;37:496-505.

43 Park J, Leong ML, Buse P, Maiyar AC, Firestone GL, Hemmings BA: Serum and glucocorticoid-inducible kinase (SGK) is a target of the PI 3-kinase-stimulated signaling pathway. EMBO J 1999;18:3024-3033.

44 Burton PB, Yacoub MH, Barton PJ: Cyclin-dependent kinase inhibitor expression in human heart failure. A comparison with fetal development. Eur Heart J 1999;20:604-611.

45 Smith MA, Zhu X, Lee HG, Harris PL, Fortino AE, Perry G, Castellani RJ: Sequestration of p27 within the cytoplasm of cardiac myocytes in chronic ischemic heart disease: pathogenic implications for ischemic cardiomyopathy. Age (Dordr) 2006;28:85-91.

46 Carrano AC, Eytan E, Hershko A, Pagano M: SKP2 is required for ubiquitin-mediated degradation of the CDK inhibitor p27. Nat Cell Biol 1999;1:193-199.

47 Larrea MD, Hong F, Wander SA, da Silva TG, Helfman D, Lannigan D, Smith JA, Slingerland JM: RSK1 drives p27Kip1 phosphorylation at T198 to promote RhoA inhibition and increase cell motility. Proc Natl Acad Sci U S A 2009;106:9268-9273.

48 Schiappacassi M, Lovisa S, Lovat F, Fabris L, Colombatti A, Belletti B, Baldassarre G: Role of T198 modification in the regulation of p27(Kip1) protein stability and function. PLoS One 2011;6:e17673.

49 Zhao D, Besser AH, Wander SA, Sun J, Zhou W, Wang B, Ince T, Durante MA, Guo W, Mills G, Theodorescu D, Slingerland J: Cytoplasmic p27 promotes epithelial-mesenchymal transition and tumor metastasis via STAT3-mediated Twist1 upregulation. Oncogene 2015;10.1038/onc.2014.473

50 Wyatt AW, Hussain A, Amann K, Klingel K, Kandolf R, Artunc F, Grahammer F, Huang DY, Vallon V, Kuhl D, Lang F: DOCA-induced phosphorylation of glycogen synthase kinase 3beta. Cell Physiol Biochem 2006;17:137-144.

51 Mraiche F, Fliegel L: Elevated expression of activated $\mathrm{Na}(+) / \mathrm{H}(+)$ exchanger protein induces hypertrophy in isolated rat neonatal ventricular cardiomyocytes. Mol Cell Biochem 2011;358:179-187.

52 Diniz GP, Carneiro-Ramos MS, Barreto-Chaves ML: Angiotensin type 1 receptor mediates thyroid hormoneinduced cardiomyocyte hypertrophy through the Akt/GSK-3beta/mTOR signaling pathway. Basic Res Cardiol 2009;104:653-667. 